\title{
The Art of Australian Political Biography
}

\section{Geoffrey Bolton}

Real intellectuals do not do political biography. Biography as a genre is suspect because it lends itself to a discourse of old fashioned narrative, beginning with the life and parentage of the subject and heading predictably towards death and posthumous reputation. Political biography is doubly suspect because it carries with it a whiff of the 'great man in history' heresy. This suggests that if Halifax and not Churchill had become prime minister of Britain in 1940, or if Al Gore had won the presidential elections in the United States in 2000, the world somehow would not have been absolutely identical to the world we know today. Political biography, at least since Plutarch nearly two thousand years ago, is also prone to contamination with a moral agenda, or at the very least to an implication that the lives of past statesmen may convey lessons and examples to the political leaders of our own generation. (And my use of the term 'statesman' will alert the perceptive reader to the further danger that, since individuals of the masculine persuasion have traditionally exercised political power, political biography is ineradicably flawed with gender bias.)

So it is that the practitioner of political biography may be compared to an old-fashioned craftsman in an Alpine village laboriously carving cuckoo clocks by time-honoured methods, while in the big town in the valley below the Swatch factory is turning out bright new up-to-the-minute products replete with every new device fresh from the laboratories of culture studies and post-modernism. Yet, curiously, political biography survives. Even the most transient and mediocre of American presidents is embalmed in a mausoleum of four, five, or six fat volumes, with a library of presidential papers the pride and joy of his home town campus.

The monuments of British prime ministers are hardly smaller. Churchill lies entombed in the million words of the official eight volume biography by Randolph S. Churchill and Sir Martin Gilbert (1966-88), though I have yet to meet the brave soul who could swear, hand on heart, to have read every word. Most would prefer the mercifully succinct account and the practical insights provided by another veteran of the House of Commons, Roy Jenkins (2001). Macmillan, surprisingly for a man of his wit and presence, erected his own grey six-volume cenotaph (1966-1973). Australian political biography as yet may claim to be fairly free of such gigantism. Even two volume biographies, such as La Nauze on Alfred Deakin (1965), Fitzhardinge on Hughes (1964; 1979) or Allan 
Martin on Menzies (1993; 1999), present themselves apologetically, although their subjects were pre-eminent in their generation.

It is therefore with a sense of taking the easy option that I state that this essay intends to confine itself to Australian political biography, and specifically to the biography of politicians since introduction of responsible government in the middle of the nineteenth century. The lives of the founding governors, Phillip and Macquarie, Arthur and Franklin, Stirling and La Trobe, raised different questions within a different context of imperial administration. I intend to chart selectively the development of political biography in Australian historiography, concentrating on examples which throw light on three questions:

- The self-consciousness or otherwise with which political figures concern themselves with their reputation in the eyes of posterity and take care to shape the record accordingly.

- The extent to which the public career of a political leader may be satisfactorily analysed with exploration into the inner recesses of his or her private life.

- The survival of Plutarch's ghost or, in other words, the political biographer's temptation to write about a deceased politician as commentary on the politics of the present day.

These are all questions of immediate relevance to myself, since I am engaged on a biography of Sir Paul Hasluck and find myself confronted with each of them.

Sir Henry Parkes was the nineteenth century politician most obviously aware of his own place in history. This became plain during the centenary celebrations for New South Wales in 1888. His proposal that Centennial Park should become the site for a national mausoleum for eminent Australians foundered, among other reasons, on the suspicion that the 73-year-old premier had his own agenda about who might be among its first occupants. Parkes went on to publish his autobiographical 50 Years in the Making of Australian History, and at his death in 1896 he became almost immediately the subject of a biography by Charles Lyne. Undoubtedly Parkes looked over his shoulder at the reputation won by his exact contemporary, Sir John A. Macdonald, as architect of Canadian confederation, with whom he was sometimes compared. But despite the generous tributes paid to Parkes when federation was achieved in 1901, and despite his early recognition when the first precincts in Canberra were named, there was no move for a more considered account of his career than Charles Lyne's. Perhaps he was seen as too exclusively a New South Wales identity; perhaps his marital history was an embarrassment; perhaps it was simply that in the early twentieth century Australian historical writing was mainly bound up with exploration and settlement, and politicians possessed less appeal.

From time to time during the 1920s an obituary volume appeared commemorating a State politician - H. C. Perry on Sir Robert Philp, for instance, or Sugden and 
Eggleston (1931) on George Swinburne, but their reception was modest. Perhaps neither was seen as a figure quite of the first order. It might have been thought that the making of the Australian Commonwealth would provide a stimulus for nationalist biographers, especially after death claimed so many of the founders - Barton, Reid, Deakin, Griffith, Forrest, Fysh — in a sweep between 1918 and 1920. This, however, was slow in coming.

Barton was sufficiently aware of his place in history to spend a considerable amount of time with his wife in destroying those parts of their correspondence which they did not wish to remain on the public record, though fortunately for the historian they were not entirely thorough. Deakin, as so often the most systematic of them all, kept orderly newspaper cuttings and correspondence. In his retirement, despite his gathering decrepitude, he went through his diaries and identified those entries which he judged of greatest historical significance. When I was writing my biography of Barton, I thought seriously of acknowledging his usefulness as a research assistant.

His family commissioned Walter Murdoch to write a biographical work about him within a few years of his death. Murdoch, already an admirer, produced a portrait (1923) which tended to entrench the Victorian view of Deakin as the main architect of Federation, and thus implicitly to play down the importance of Barton as broker of consensus or Reid as the canny bargainer who ensured the essential presence of New South Wales in the Commonwealth. Because of the later pre-eminence of Melbourne in the production of Australian history this view has dominated Australian historiography. One would not wish to over-compensate by removing Deakin from his pedestal, but his reputation stands as reminder to statesmen to bequeath orderly archives to appreciative historians. By the end of the 1920s the National Library of Australia was starting to establish itself as the receptacle for manuscript collections of potential historical importance. The Barton archives was one of the first collections to find its way there and Deakin's papers followed before long.

Federation as a sustaining myth for Australian materialism was eclipsed during the 1920s and 1930s by the story of ANZAC and the Official History of Australia in the War of 1914-1918 as edited by Charles Bean stressed the part played by the rank and file rather than the achievements of individual generals. Another discourse which might lend itself to political biography could be found in the history of the Australian Labor movement, though the splits of 1916 and 1931 made it hard to identify figures who could be seen as sustaining Labor ideals throughout their lives. Dr H. V. Evatt, whose importance in Australian historiography has been overshadowed by his controversial political record, tackled these issues.

Evatt's first excursion into the field, The Rum Rebellion, is admittedly little better than a defence counsel's argument in favour of Captain William Bligh, to whom 
in some respects Evatt himself bore an uncanny resemblance. But in 1940 he produced Australian Labour Leader: The story of W.A. Holman and the labour movement, a biography of a hero of his youth, William Holman, who had seemed a brilliant State premier before the conscription crisis drew him into the Nationalist ranks in 1916-17. Evatt's biography is too long, and it has its indulgent moments, as when he introduces several political ditties from the Sydney University students, which he very probably wrote himself, but after more than sixty years it has yet to be supplanted. Knowing that in the early years of the Second World War Evatt, then a newcomer in federal politics, played with the concept of an all-party coalition. The question arises as to whether he regarded Holman as an example or a warning.

It was to be twenty years before a similarly significant biography of a Labor leader was to be produced. When L. F. Crisp published Ben Chifley in 1961 its underlying agenda was very different. Chifley as wartime Treasurer, and as Prime Minister from 1945 to 1949 , had been a major architect, if not the major architect, of post-war reconstruction and the creation of a policy which placed full employment and access to social opportunity foremost among its goals. Most of these goals were sustained by the Menzies Coalition government after 1949, but the Federal Labor party under Evatt disintegrated into schism and what seemed an eternity in opposition. Crisp and several others who had been prominent young standard bearers of post-war reconstruction in administrative positions under Chifley found refuge in Canberra University College and in the Australian National University. In the late 1950s and early 1960s they resembled a little colony of Jacobite exiles hoping against hope that the King would come into his own.

Crisp presented Chifley as a sagacious and practical statesman, almost without fault, whose vision Labor needed to recover. Chifley had served the nation well while remaining faithful to his party and its principles, but a feckless electorate beguiled by the promise of consumer goods and an end to rationing had failed to appreciate his quality. So Crisp hoped to keep aglow the light on the hill during the barren years of opposition. It was a very good biography, but it might have been even better with a little more shade to the light, and it had one surprising omission. Late in his research Crisp discovered that in the 1920s Chifley went overseas for the first time, working his passage on a steamship to South Asia to observe conditions there at first hand. Unaccountably he decided to ignore this episode though it would have enhanced Chifley's reputation for foresight and concern for social justice.

Crisp published in 1961 at a moment when The Australian National University had recently taken probably the most momentous step to promote biography in the history of Australian scholarship. Inspired by L. F. Fitzhardinge and energised by Sir Keith Hancock, the production of the Australian Dictionary of Biography 
grew into a unique example of major co-operative humanities research which has endured for nearly half a century. Its importance for the writing of political biography lay partly in the dozens of essays on political figures commissioned for its seventeen volumes, ranging from the numerous 500 word sketches of third-order parliamentarians to the 5000 or 6000 words required for heavyweights such as Menzies or Evatt. At their best these articles, drafted in conformity with the house style of the $A D B$, attain the simple perfection of a haiku or a sonnet; Geoffrey Serle's studies of major and minor worthies of late nineteenth century Victoria are elegant masterpieces, and would probably repay anthologising. These articles in turn created a bank of research data that could be quarried by authors seeking to write about an individual at greater depth. In some cases also, $A D B$ articles stimulated authors to go on to attempt a full scale biography, or at the very least enabled authors with a full-scale work in their sights, such as Allan Martin with Henry Parkes, to rehearse the arguments and explore the issues which they proposed exploring in greater depth.

Within The Australian National University, Laurie Fitzhardinge with W. M. Hughes (1964; 1979) and John La Nauze with Deakin (1965) set high standards of political biography, though in each case it could be argued that they scored higher in treating their subject's public character than in understanding their private personalities. An old-fashioned gentlemanly reticence may have restrained Fitzhardinge from some revelations, but it is surely relevant that in old age Hughes confessed to the diplomat Malcolm Booker (who later published it in his own biography) that, as a scrawny young new chum knocking around the back blocks of Queensland, he (Hughes) lived in fear of homosexual rape. This must throw light on Hughes's attitude to the possession and use of power in a Hobbesian world of potential violence. Hughes was also an unsatisfactory family man, who more or less repudiated the six children of his first, probably de facto wife, of whom Fitzhardinge makes brief mention, and who behaved badly over the death in illegitimate childbirth of the daughter by his second marriage about which Fitzhardinge must almost certainly have known more than he wrote. I shall return to this issue of the interface between private and public life later.

La Nauze could convincingly describe Deakin as a devoted husband and parent, and faced no such dilemma. He was, however, temperamentally unsuited to sympathetic explanation of Deakin's mystical streak, at one point wryly commenting that the young man would have been better off playing cricket than pondering over Swendenborgian metaphysics. It was left to Al Gabay (1992) to make good the omission in a monograph which largely confines itself to Deakin the mystic without exploring very far the implications for his political life. For the biographer there remains a problem of reconciling Deakin's preoccupation with ethical standards with his capacity to inspire mistrust in many of his contemporaries. When Hughes attacked Deakin as one who had joined all parties and betrayed all parties, it may have been a cheap shot, but there was a sting 
in it appreciated by many. Blunt Sir John Forrest after a long association decided that Deakin was not a safe man to go tiger-shooting with. And in our own time Frank Crowley has commented on the paradox of a senior Commonwealth cabinet minister accepting pay from a conservative London daily (the Morning Post) for anonymous articles about Australian affairs. In these Deakin affected the persona of one who was sometimes quite critical of the policies of the Federal ministry. Some of the subtleties in 'Affable Alfred' remain to be teased out.

Not all the interactions between private and public characters were necessarily scandalous or contentious. It was, for instance, a strength of Crisp's account of Chifley when he noted that for several years in his boyhood Chifley was sent away from his parents and two younger brothers to live with a rather taciturn and solitary widowed grandfather. Crisp could legitimately argue that this experience helped to shape Ben Chifley into the self-reliant but not particularly gregarious adult in public life.

Some biographers have wondered if use might be made of the insights of psychology and psychotherapy as a systematic aid to the explanation of historical character. Martin for a time was attracted by the ideas of Erik Erikson (1959), who postulated that emotional growth through a human lifetime depended on successfully confronting eight developmental crises at different points in the life-cycle. Although traces of his approach lingered in the final version of his biography of Parkes, Martin came largely to discard Erikson's model in favour of a more empirical approach to the evidence. Little trace of it may be found in his later two-volume life of Menzies, but it may still be that the questions Martin put to his source materials were sharpened by acquaintance with Erikson's theories.

James Walter (1980) has made the most thorough application of psychological theory to biography in his study of Gough Whitlam, The Leader. Many of his findings are valid and plausible, but debate will inevitably continue as to whether a different historian without theoretical foundations might have arrived at very similar conclusions through observation of available evidence. In recent years there seem to have been fewer examples of the conscious use of psychological theory as a biographical tool. Recent attempts by North American and British historians to plot family history by using the concept of genograms - models in which patterns of behaviour are shown to have a tendency to replicate themselves over several generations - have not to my knowledge been widely attempted in Australia. But perhaps Joy Damousi's recent Freud in the Antipodes (2001), describing the growth of psychoanalytical thought in twentieth century Australia, will turn scholarly inquiry once more to the possible nexus between psychoanalysis and biography. If so, due attention must be paid to the difficulty of transferring the psychotherapeutic techniques used with a living client to the understanding of a dead politician. 
This question of the interface between private and public character keeps coming back to me in attempting the biography of Paul Hasluck. At the most obvious it lies in the widely held perception that there was a striking disjunction between his private self and the persona which he presented in ministerial office. The contrast was, in the words of one who knew him, 'schizophrenic'. The public Hasluck was seen as aloof, pedantic, demanding, censorious, a hard and often unappreciative taskmaster. It was notorious that at the January 1968 contest for the party leadership, in contrast to the energetic campaigning of Gorton and the frenetic lobbying of McMahon to retain the deputy leadership, Hasluck remained aloof, not even engaging in casual party room conversation on the morning of the election. By contrast, there is equally wide testimony that the private Hasluck was warm, hospitable, and considerate, an intelligent and lively minded conversationalist but one who was perhaps never happier than when yarning with the stockmen at a bush camp.

He belonged to a generation who set greater store than our own on formal behaviour in public, but there is not the same sense of contrast between the public and private personas in Menzies or Chifley or Evatt or McEwen. There is a recognisable continuum between the personality on or off duty. Hasluck's administrative style can be readily explained as a reaction against his five years working under Evatt as minister, with his erratic and chaotic business habits, his suspiciousness, his readiness to play favourites. But is that sufficient explanation requiring no exploration of the private man?

Another perplexing facet of Hasluck's personality lies in what might be called his 'Prince Hal' syndrome, his tendency to turn away from and repudiate activities in which he had seemed deeply engaged. He was a pioneer oral historian as a young man in Western Australia. His interviews with elderly pioneers, taken in Pitman's shorthand and subsequently typed up, offer uniquely valuable insights into the first and second generations of settlers in the mid-nineteenth century colony. As late as 1948, when he was researching for his volumes of the Official History of Australia in the Second World War (1952; 1970), he could write to Robert Menzies that 'the unrecorded pages of history ... could only be written down from the memory of those who took part'. But in later years he disparaged oral history as subjective and unreliable. He was a proficient journalist, apparently popular with his fellow journalists, but as a politician he could be scathing about the profession. He was a respected officer of the Department of External Affairs in the 1940s, but his comments about diplomats and the public service in old age are seldom flattering. He led the life of politics for eighteen years but his judgments of his colleagues in The Chance of Politics (1997) - and that book is an edited selection from which the most wounding comments have been left out - are perceived by not a few readers as harsh. He was no more sparing of himself than he was of other people. From where did this come, this inability to be satisfied? 
Here the practice of other biographers may be helpful. But some, such as Tim Rowse in writing about H. C. Coombs, have adopted a self-denying ordinance about exploring their subject's private life. Deference to the feelings of people still living may call for such reticence, and a skilful historian or biographer can often use the public record to arrive at conclusions compatible with what is known but not stated about the private record. There is nevertheless disappointment when, in a generally lively and informative study of the first Labor prime minister, Chris Watson, Ross McMullin (2004) tersely informs us that Watson's premature retirement from federal politics was due to his wife's complaints about his frequent absences from home in Sydney. One would never know that Watson's concern for his wife arose partly because his presence helped her in a battle against alcoholism, nor that after her death he re-married and somewhat belatedly found fulfilment as a parent. As I say, this does not detract from the quality of McMullin's assessment of Watson's public career, but is more required of a biographer?

Where private experience is presented as shaping a public persona it is often the experience of childhood and adolescence which serves as evidence. Crisp's account of Chifley's isolated childhood is one such case. The discovery by Chris Cunneen (2000) that William McKell's father deserted his family and went off to that land of bigamous opportunity, Western Australia, is another, since the responsibility thrust upon the eldest boy of the family helped to shape the attributes and political beliefs of the adult William McKell. David Day is one of the few recent political biographers to attempt to chart the interface between an adult politician's public and private lives, and this is commendable, but in my view the results are uneven. He shows convincingly that Curtin's battle against alcoholism was more protracted than has previously been supposed, and that his ultimate break with the booze was not as clear-cut as other writers made it out to be; but ultimately Curtin's defeat of his demons is more credible as a result.

On the other hand, I am not quite convinced by Day's effort to show that Chifley's relationship with his secretary, Phyllis Donnelly, was actively sexual. Duncan Waterson's tactful phrase, 'affectionate friend', suggests a surer sense of nuance. The world of Chifley's generation contained numerous examples of secretaries who became 'office wives', women whose potential husbands were killed in the First World War. They devoted themselves loyally to their boss, fetched and carried for him, protected his privacy, brought order into his working life, and sought no career outside his service. Sometimes, as Ross Fitzgerald (1994) shows in his life of E. G. Theodore, the employer's wife became jealous of the secretary's emotional closeness. Sometimes, as with Sir John McEwen, he married his secretary after his first wife died. But in the generation of Chifley and Phyllis Donnelly, both products of Catholic culture, desires often remained unacted. We must not bring anachronistic expectations to bear. 
When I wrote about Edmund Barton, I found that his sexual and emotional life, like much of his personality, was relatively uncomplicated. He fell in love at the age of twenty-one, courted Jeanne Ross patiently for seven years until they could afford to marry, and lived happily ever after despite debts and frequent absences from home until he achieved the financial security of a seat on the High Court bench. The problem about Barton lay in his notorious reputation for indolence contrasting with his demonstrably hard work at the two federal conventions. His medically qualified grandson, David Barton, wrote to me that Edmund's behaviour was bi-polar in origin, so that in periods of depression he indeed found solace in food, drink and inactivity, while at other times he could draw on reserves of concentrated energy. This was a hypothesis for which I had not been able to find any contemporary recognition, but a medical opinion buttressed by the weight of family authority was good enough.

Guided by this insight, it was possible to identify two periods in Barton's life when after a period of strenuous activity and pressure he had lapsed into the lethargy and overindulgence of which critics complained. In 1893, having survived the Broken Hill strike and the threatened collapse of the banking system, he was overtaken by a crisis in his personal finances, and fell into the pattern of overeating and drinking as a symptom of depression. His perceptive premier, Dibbs, sent him with his wife on a government-funded sea cruise and recovery followed. In the early months of 1902, after the achievement of Federation and the crowded first session of Federal Parliament, living away from home in makeshift quarters, he underwent another bout. His friends and colleagues, Alfred Deakin and Richard O'Connor, had to cover for him, and this episode understandably coloured Deakin's recollections of Barton, and hence the assessments of later historians relying on Deakin as a source. The health of the private Barton influenced his public performance and hence the judgment of historians and biographers coming later.

My question about the extent to which politicians are conscious of the verdict of posterity, and take care that the record shows them in a favourable light may not reflect a widespread problem. Biographers are probably more often exasperated by the failure of their subject to leave adequate evidence. With Paul Hasluck, however, we are dealing with a man who was already a good historian before he became a politician and cabinet minister. He was acutely aware of the demands of the historical record. It is not just that in retirement he published several substantial books reflecting on aspects of his public career. The possibility remains that during more than seventeen years in a diligent ministerial career every minute which he penned on a departmental submission, every submission carried to cabinet, was written in expectation of the scrutiny of the future.

This is a different problem from the more usual one of coping with the rationalisations and self-justifications which appear in the autobiographies 
written by politicians after their retirement (though some of these personal accounts, such as those by Bill Hayden and Neal Blewett, make useful contributions to the understanding of their period). It is different again from the challenge inherent in reading Don Watson's Memoirs of a Bleeding Heart (2002), a work that is neither quite autobiography nor quite biography. No future biographer of Paul Keating will be able to escape the shaping influence of Watson's account, written as it is with immediacy and insight. It is not just a matter of commemorating the style and content of Keating's administration and perhaps contrasting it with the cautious and measured pragmatism of Keating's successor. Because Watson is less adulatory of Keating than Crisp was of Chifley, he may be acquitted of writing a tract to hearten the faithful during the long years of opposition. But he has to some extent given a decisive turn to future historiography, and no doubt he intended to do so.

In Australia we are immediately up against the tendency of the general public to believe that the politicians of their youth were figures of greater stature than the pygmies in public life today. Howard and Beazley are no match for Fraser and Whitlam; but twenty years ago Curtin, Chifley and Menzies were extolled as Australia's greatest prime ministers. Only an ancient like myself can remember that in their years of office they were often compared unfavourably with the likes of Deakin and Fisher and Hughes. Sometimes it is the misfortune of a politician to become associated with causes which are currently out of fashion. George Reid, for example, could be seen as a lonely anachronism in espousing free trade in an era of liberal protectionism. He was further ill-served by Deakin's pen-portraits of him as little more than an artful buffoon, but W. G. McMinn's biography (1989) put paid to that stereotype. Now that tariff protection is no longer in favour and free trade in the form of globalisation is the dominant orthodoxy, Reid is in the process of resurrection as a harbinger of social policy. In like manner Henry Reynolds has rehabilitated Bruce Smith, previously dismissed as a spokesman for employers who wanted to introduce cheap non-European labour into White Australia, as a tolerant multiculturalist ahead of his time. The fluctuations of the biographical stock market are fascinating.

For me these questions arise insistently in the case of Hasluck, since he was deeply implicated in two seriously contentious issues: the shaping of Aboriginal policy and Australia's involvement in the Vietnam war. Hasluck's involvement in Aboriginal policy puts me in mind of Lord Melbourne's cynical aphorism: 'You had better try to do no good, and then you'll get into no scrapes'. In the 1930s and 1940s Hasluck was one of the earliest advocates of a better deal for Australian Aborigines, his first major publication Black Australians (1942) breaking the great Australian silence that had largely written them out of the history books. In twelve years as Minister for Territories, from 1951 to 1963, he did much to influence Aboriginal policy, and as a result now stands condemned by many as the apparent architect of the policy of removing Aboriginal children 
from their parents. Some passages of the Bringing them Home report ${ }^{1}$ may be read as implying this, but Hasluck only endorsed the practice as a last resort.

The situation has not been helped by historians such as Geoffrey Partington (1996) who have set Hasluck up as a wise paternalist contrasted with his contemporary Coombs and his quixotic ideals of Aboriginal autonomy. It is relevant that Hasluck's main impact on policy came in the 1950s, when it was possible to hope that Aborigines, especially in northern Australia, might find employment not only in the traditional pastoral industry but through agriculture, mining and forestry without disruption to their culture. Coombs came to Aboriginal policy in the late 1960s, by which time Aborigines had been displaced from the cattle stations and new social problems had arisen for which solutions were needed. In assessing both men, a biographer in the early twenty-first century must sedulously avoid applying the insights and criteria of today.

Similarly with the Vietnam war. The thirtieth anniversary of the fall of Saigon has brought forward revisionists justifying the American intervention and therefore the Australian participation in that conflict. Within Australia a school of historians beginning with Michael Sexton (1981) and Greg Pemberton (2002) have portrayed Australia as the willing tool of the Americans, even as goading-on Washington to greater intervention. In the current state of my research I find that in the year preceding Australia's decision of April 1965, which was Hasluck's first year as Minister for External Affairs, there was often a perplexed lack of clarity in Canberra about American intentions. Hasluck, indeed, insisted to his colleagues that Vietnam was a more serious problem for Australian security than the confrontation between Indonesia and Malaysia, but when Menzies decided that Australian troops should be sent to Vietnam, Hasluck demurred and unavailingly suggested caution. (It must have irked him that his only ally among senior cabinet ministers was McMahon, whom he despised.) It is my hope that a Hasluck biography may encourage a more nuanced approach in the writing of the recent general history of Australia.

In his report on the National Museum of Australia John Carroll (2003) suggested that its historical section should give greater salience to Australian heroes (he weakened his case by including among his examples Burke and Wills, surely the most tragically incompetent of explorers.) There will always be a public appetite for heroes and villains, Ned Kelly against Sir Redmond Barry, but this is not the proper business of historians and biographers. Political biographers in particular must learn to live with ambiguity, and to learn to present their materials skilfully enough to persuade their readers to accept ambiguity. Actors in politics such as Parkes or Barton or Curtin may live much of their careers in the same mundane and contradictory muddle as the rest of us without losing the capacity to touch greatness in a moment of crisis, or at other moments to fall 
Australian Political Lives

below their best. With all respect to John Carroll I find greater wisdom in that aphorism of Bertolt Brecht: 'Happy is the land that has no need of heroes'.

\section{ENDNOTES}

${ }^{1}$ Human Rights and Equal Opportunity Commission (1997). Bringing them home: report of the National Inquiry into the Separation of Aboriginal and Torres Strait Islander Children from their Families, (Commonly known as Stolen children report or Stolen generations report) Parliamentary paper no. 128. 